\title{
The Role of Advanced Technology Product Animations on Informing Patients with Gonarthrosis Preoperatively
}

\author{
Gonartrozlu Hastaların Preoperatif Bilgilendirilmesinde İleri Teknoloji Ürünü \\ Animasyonların Rolü
}

(D) Alican Barış, (D) Yusuf Öztürkmen

İstanbul Training and Research Hospital, Clinic of Orthopaedics and Traumatology, İstanbul, Turkey

\begin{abstract}
Introduction: This study aimed to investigate the effect of visual animations on the patient's knowledge and satisfaction level in the informing during informed consent of the patients scheduled for total knee replacement surgery.

Methods: A total of 139 patients who were diagnosed with gonarthrosis and scheduled for total knee replacement surgery in our clinic were included in the study. Verbal and written information about diagnoses, disease findings, scheduled surgery, operation stages, other treatment options other than the scheduled surgery, and specific complications of scheduled surgery were given to the patients. The information levels were measured with open-ended questions. After 35 days, on average, a visual animation that included the findings of their diseases and the stages of the surgery planned was shown. The impact of visual animations on the knowledge level and patient satisfaction were examined. The relation between this impact and the education level of the patient was also investigated.

Results: Visual animations statistically and significantly increased the knowledge level of patients and the level of their satisfaction in informed consent $(p=0.001 ; p<0.01$, respectively). It was determined that this increase was independent of the education level of the patients ( $p>0.05)$.
\end{abstract}

Conclusion: Visual animations are a simple, easy, and effective method for informing during informed consent.

Keywords: Informed consent, patient satisfaction, visual animations, gonarthrosis, total knee arthroplasty

\section{öz}

Amaç: Bu çalıșmanın amacı; total diz protezi ameliyatı planlanan hastalarda; aydınlatılmış onam esnasındaki bilgilendirmenin görsel animasyonlar ile desteklenmesinin hastadaki bilgi ve memnuniyet düzeyine etkisinin araştırılmasıdır.

Yöntemler: Kliniğimizde gonartroz tanısı alan ve total diz protezi ameliyatı planlanan 139 hasta çalışmaya dahil edildi. Hastalar; tanıları, hastalığın bulguları, planlanan ameliyat ve ameliyatın aşamaları, planlanan ameliyat dışındaki başka tedavi seçenekleri, planlanan ameliyata özgü komplikasyonlar hakkında sözlü ve yazılı olarak bilgilendirildi. Açık uçlu sorular ile bilgi düzeyleri ölçüldü. Ortalama 35 gün sonra hastalıklarının bulguları ve planlanan ameliyat aşamalarını içeren görsel animasyon uygulaması gösterildi. Görsel animasyonların bilgi düzeyine ve hasta memnuniyetine etkisi ile bu etkinin hastanın eğitim düzeyi ile ilişkisi araştırıldı.

Bulgular: Görsel animasyonlar; hastaların bilgi ve bilgilendirilmiş onam şeklinden duyulan memnuniyet düzeyini istatistiksel olarak anlamlı derecede artırmıştır ( $p=0,001$; $p<0,01)$. Bu artıșın hastaların eğitim düzeyinden bağımsız olduğu belirlenmiştir ( $p>0,05)$.

Sonuç: Görsel animasyonlar aydınlatılmış onam esnasında yapılan bilgilendirmede basit, kolay, etkili bir yöntemdir.

Anahtar Kelimeler: Aydınlatılmış onam, hasta memnuniyeti, görsel animasyonlar, gonartroz, total diz artroplastisi

\section{Introduction}

Total knee arthroplasty is a surgical procedure that relieves pain in knee osteoarthritis, improves the functions of the knee joint, and increases the patient's quality of life (1). In the coming years, total knee replacement demand is expected to increase exponentially (1-3). It is a surgical procedure open to complications despite increasing demand, advances in implant design, excellent results, developments in the technique, and rehabilitation $(1,3,4)$. Patients who undergo total knee replacement are usually elderly. This situation brings risks during and after surgery $(5,6)$. Therefore, the patient should be sufficiently informed about the possible risks and complications of this operation. This informing is provided with the informed consent process. Informed consent is based on the decision-making principle of the person and forms the basis of the doctor-patient relationship (7). Every patient has the right 
to know and determine what shall be done to his/her body. The fact that legal regulations guarantee this right gives the health workers the responsibility of informed consent (8). Also, the lack of informed consent of the individuals before the medical procedure or the failure to obtain it appropriately causes essential ethical and legal problems in clinical practice (9). The conventional informed consent is generally in the form of insufficient written texts $(10,11)$. Studies show that patients do not understand the main elements of the consent in their informed consent performed with written or verbal information (10,12-15). In particular, it is seen that elderly patients with gonarthrosis cannot read written informing texts, or they are too lazy to read them. In order for the information during the informing process to be permanent in the mind of the patient, the patient should be aware of stimuli and allow them to be stored in memory. The use of visual images and symbols during informing allows the individual to give more attention to the informing; also, images are more memorable than words $(10,14,16)$. In the present study, it was aimed to evaluate the available knowledge levels of the patients who had gonarthrosis and were informed with standard verbal and written texts, and the changes in their levels of knowledge after visual animation.

\section{Methods}

Necessary permissions [istanbul Training and Research Hospital, Clinical Research Ethics Committee; with (decision no: 757, date: 15.01.2016)] were obtained for the implementation of the research. A total of 139 patients, who were admitted in our clinic between January 2016 and September 2018 with gonarthrosis diagnosis, who were not relieved from their complaints despite conservative treatments, and who had undergone total knee arthroplasty, were included in the present study after their consents were received as volunteers in the study. Gender, age, educational status, diagnosis, and scheduled operation information of the patients were recorded. In the outpatient clinic conditions, the participating patients were informed verbally and in writing about diagnoses and the findings of their diseases, the planned surgery and the stages of it, other treatment options other than the planned surgery, and the complications of the planned surgery. Each informational stage was limited to six items in order to evaluate the results of the informing objectively (17-19). After verbal and written informing, available knowledge levels of the patients were determined by asking open-ended questions (20-23). The correct answers given to each open-ended question were scored with numbers $0-6$ following the number of information given before. Zero point was given to the patient who did not know any of the items in the informational stage, and 6 points were given to the patient who knew all items (6 items) in the informational stage. After the surgery appointments were given to the patients, they were admitted to the orthopedics service to be operated after an average of 35 days (20-58). The animation showing the findings of their disease and the planned surgery stages (Knee Pro III version: 3.8.1, 3D4 Medical's NOVA3 technology application) was shown on the tablet computer (iPad Wi-Fi 128 GB Black; Apple, California) (Figure 1). Although there were no visual animations, explanations were made on other treatment options and complications specific to their surgery over the figures in the visual animations. The patients' knowledge levels after the animation representation were determined by asking the same open-ended questions again. The knowledge levels after the animation representation were also scored with numbers from 0 to 6 in the same way (the correct answers to each open-ended question are following the number of information given before). Zero point was given to a patient who did not know any of the items in the informational stage, and 6 points were given to a patient who knew all items ( 6 items) in the informational stage. Also, the satisfaction with the written-oral informed consent and the satisfaction with the visual animation and informed consent were scored with a number between 0-6. The data that were obtained in this way were compared statistically.

\section{Statistical Analysis}

Number Cruncher Statistical System 2007 (Kaysville, Utah, USA) program was used for statistical analysis. In the assessment of the study data, the Mann-Whitney $U$ test was used in the paired comparisons of the variables that did not show the normal distribution in the comparison of quantitative data in addition to the descriptive statistical methods. Kruskal-Wallis test was used in the comparison of three and more groups that did not show normal distribution. Wilcoxon signed ranks test was used for intra-group comparisons of the variables that did not show normal distribution. Statistical significance was evaluated at $p<0.01$ and $p<0.05$ levels.

\section{Results}

The distribution of the demographic characteristics of the patients participating in our study is shown in Table 1. When compared to the knowledge and satisfaction levels of the patients before the animation; after the animation, it was seen that there was a statistically significant increase in the levels of knowledge about the findings of disease, stages of surgery, alternative treatment options, information about surgeryspecific complications, and the levels of satisfaction in the format of obtaining the consent (Table 2$)(p=0.001 ; p<0.01$, respectively). It was detected that there was no statistically significant difference in the relationship of the changes of the parameters according to before and after animation with the education status of the patients (Table 3) $(p>0.05)$. Animations increase the knowledge and satisfaction levels of the patients independently from the level of education.

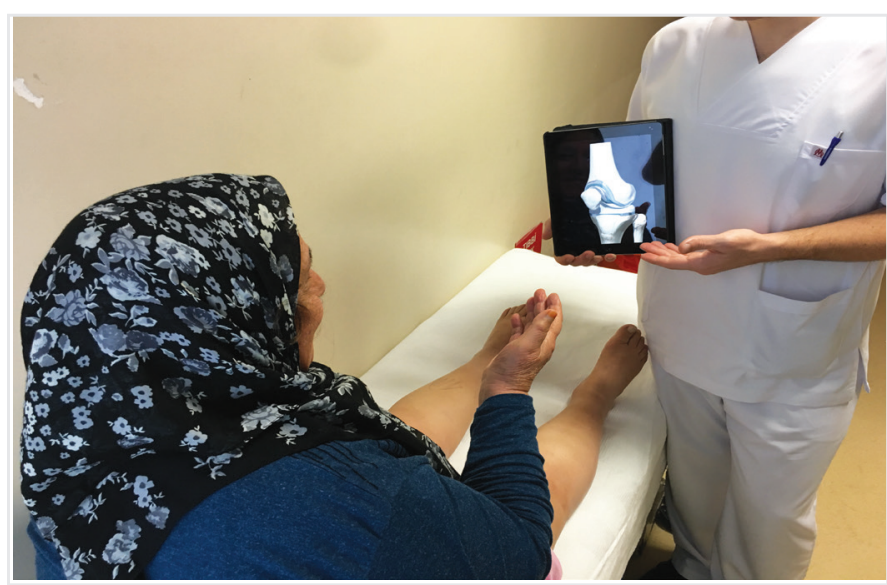

Figure 1. Image of patient watching visual animation 


\section{Discussion}

Informed consent based on the principle of respect for autonomy before medical intervention is a legal obligation that should be implemented in many countries, including our country. A significant number of lawsuits against health professionals are caused by the lack of or insufficient informed consent $(9,24,25)$. The patients' levels of understanding

Table 1. Distribution of demographic characteristics

\begin{tabular}{|l|l|l|l|}
\hline \multirow{2}{*}{ Age (year) } & & Min-max & Mean \pm SD \\
\hline \multirow{2}{*}{ Gender } & Female & $\mathbf{5 4 - 7 8}$ & $\mathbf{6 6 . 6 3} \mathbf{4 . 3 6}$ \\
\hline & Male & 113 & $\%$ \\
\hline & Literate & 26 & 81.3 \\
\hline \multirow{2}{*}{ Education status } & Primary school & 63 & 18.7 \\
\hline & Secondary school & 20 & 20.1 \\
\hline & High school & 23 & 45.3 \\
\hline & University & 5 & 14.4 \\
\hline Min: minimum, Max: & maximum, SD: standard deviation & 16.5 \\
\hline
\end{tabular}

and remembering the information given in informed consent may be different. The informed consent procedure, which is very useful in the surgical decision making by patients together with the physician, cannot be sufficiently remembered by the patients after some time from surgery, and this may lead to some legal problems in the lawsuits of weak enforcement (9).

In a study examining the lawsuits related to knee arthroplasty, it was seen that the most common complications were the subject of the lawsuits. The authors have an opinion that most of the allegations that led to the lawsuits in question were not caused by frequent complications. It was seen that the patients sued the surgeons when the results of the surgery were different from their expectations. The authors presented an opinion that an unsatisfactory result according to patient expectations, is a frequent cause of the lawsuit (26). In a study examining the ethical aspects of informed consent in patients undergoing total knee arthroplasty, it was detected that all patients signed the informed consent. However, in this study, $20 \%$ of the patients stated that they could not get information about their diseases, 38\% were not informed about the surgical procedure, $72 \%$ did not know about the possible complications, and $85 \%$ were not informed about the alternative

Table 2. Changes in information and satisfaction levels before and after animation representation

\begin{tabular}{|c|c|c|c|c|c|}
\hline & & $\begin{array}{l}\text { Verbal-written } \\
\text { consent }\end{array}$ & $\begin{array}{l}\text { Consent with } \\
\text { animation }\end{array}$ & Change percentage & ${ }^{a} \mathbf{p}^{* *}$ \\
\hline \multirow{2}{*}{ Knowledge about the findings of disease } & Mean \pm SD & $2.72 \pm 0.66$ & $5.02 \pm 0.65$ & \multirow{2}{*}{$92.93 \pm 41.73$} & \multirow{2}{*}{0.001} \\
\hline & Min-max (median) & $2-5(3)$ & $4-6(5)$ & & \\
\hline \multirow{2}{*}{ Knowledge about the stages of scheduled surgery } & Mean \pm SD & $2.46 \pm 0.62$ & $5.21 \pm 0.73$ & \multirow{2}{*}{$123.47 \pm 59.77$} & \multirow{2}{*}{0.001} \\
\hline & Min-max (median) & $1-5(2)$ & $2-6(5)$ & & \\
\hline \multirow{2}{*}{ Knowledge about other treatment options } & Mean \pm SD & $2.68 \pm 0.51$ & $3.53 \pm 0.66$ & \multirow{2}{*}{$36.09 \pm 37.04$} & \multirow{2}{*}{0.001} \\
\hline & Min-max (median) & $2-4(3)$ & $2-5(3)$ & & \\
\hline \multirow{2}{*}{ Knowledge about complications } & Mean \pm SD & $2.58 \pm 0.56$ & $3.45 \pm 0.62$ & \multirow{2}{*}{$38.31 \pm 32.78$} & \multirow{2}{*}{0.001} \\
\hline & Min-max (median) & $2-4(3)$ & $2-5(3)$ & & \\
\hline \multirow{2}{*}{ Satisfaction level } & Mean \pm SD & $4.93 \pm 0.78$ & $5.92 \pm 0.30$ & \multirow{2}{*}{$23.21 \pm 21.24$} & \multirow{2}{*}{0.001} \\
\hline & Min-max (median) & $3-6(5)$ & $4-6(6)$ & & \\
\hline
\end{tabular}

Table 3. Change in the informing and satisfaction levels of patients according to education status

\begin{tabular}{|c|c|c|c|c|c|c|}
\hline & & \multicolumn{4}{|c|}{ Change percentages between before and after the animation } & \multirow[b]{2}{*}{${ }^{c} p$} \\
\hline & & Literate $(n=28)$ & $\begin{array}{l}\text { Primary school } \\
(n=63)\end{array}$ & $\begin{array}{l}\text { Secondary school } \\
(n=20)\end{array}$ & $\begin{array}{l}\text { High school, } \\
\text { university } \\
(n=28)\end{array}$ & \\
\hline \multirow{2}{*}{ Knowledge about the diagnosis of disease } & Mean $\pm S D$ & $100.3 \pm 40.73$ & $90.87 \pm 41.66$ & $92.5 \pm 37.65$ & $90.48 \pm 46.74$ & \multirow{2}{*}{0.699} \\
\hline & Min-max (median) & $25-150(100)$ & $25-200(100)$ & $33-150(66.6)$ & $0-150(100)$ & \\
\hline \multirow{2}{*}{ Knowledge about the scheduled surgery } & Mean $\pm S D$ & $125.6 \pm 75.56$ & $126.98 \pm 53.25$ & $105.42 \pm 41.73$ & $126.31 \pm 67.3$ & \multirow{2}{*}{0.550} \\
\hline & Min-max (median) & $0-400(100)$ & $33.33-300(150)$ & $25-200(100)$ & $20-300(100)$ & \\
\hline \multirow{2}{*}{ Knowledge about other treatment options } & Mean $\pm S D$ & $30.36 \pm 33.96$ & $32.8 \pm 35.41$ & $41.25 \pm 40.24$ & $45.54 \pm 40.86$ & \multirow{2}{*}{0.333} \\
\hline & Min-max (median) & $0-100(33.33)$ & $0-150(33.33)$ & $25-150(33.3)$ & $0-150(33.33)$ & \\
\hline \multirow{2}{*}{ Knowledge about complications } & Mean \pm SD & $36.9 \pm 28.09$ & $35.71 \pm 31.37$ & $41.67 \pm 38.04$ & $43.15 \pm 37.06$ & \multirow{2}{*}{0.862} \\
\hline & Min-max (median) & $0-100(50)$ & $0-100(33.33)$ & $0-100(41.67)$ & $0-150(33.33)$ & \\
\hline \multirow{2}{*}{ Satisfaction level } & Mean \pm SD & $24.64 \pm 16.44$ & $19.13 \pm 19.75$ & $23.75 \pm 17.54$ & $30.6 \pm 28.73$ & \multirow{2}{*}{0.139} \\
\hline & Min-max (median) & $0-50(20)$ & $0-100(20)$ & $0-50(20)$ & $0-100(20)$ & \\
\hline
\end{tabular}


treatment methods. Also, about half of the patients signed the consent form without reading. It was stated that the readability and intelligibility of the consent form are low, and a short and understandable language should be used in consent form considering the educational status of the patients. It was also stated that multimedia resources should be used in the informed consent process (5).

In our study, the readability and intelligibility levels of the written consent forms were also found to be low in parallel with the study in question. When preparing the consent forms, the education level of the patients should be considered. However, since the educational level of the patients is different, it is not possible to prepare different consent forms for each education level. This non-practical situation will bring some ethical problems in addition to many difficulties. Visual materials, especially animations, can be easily understood by patients with every educational level, including even non-literate patients, and provides a possibility to watch many times. In another study that investigated the understanding of informed consent form in surgical interventions by patients, approximately one-third of patients stated that they did not know its importance despite having signed the informed consent form $(20,27)$. In another similar study that investigated the comprehension of the informed consent process by the patients who were scheduled for surgery, most of the patients stated that they knew the informed consent process partially, and the majority of them did not know what the informed consent form they signed was. In this study, the author concluded that the patient's knowledge about the consent process was not sufficient (28). In our study, although we had a similar opinion before the visual material representation, it was found that the patients' satisfaction in the format of obtaining the consent was high after visual materials, and they had enough knowledge about the informed consent process with open-ended questions. Informing patients before the operation reduces the fear and anxiety of patients. In a randomizedcontrolled study that was conducted with informing (in video form) in addition to the written and oral form, it was demonstrated that the form of informing patients affected anxiety before surgery; and that informing that was carried out with visual materials decreased anxiety $(29,30)$. In another similar study, before the surgery, the effect of informing as verbal or with pictures in CD-ROM on the anxiety of patients who will undergo the surgical procedure was investigated. The patients were divided into two groups. While verbal and written information was given to one group, the CD-ROM, which included pictures of surgery procedure, results, complications, and different periods of recovery, was shown to the other group. At the end of the study, it was determined that the anxiety levels increased significantly in both groups when the surgery day approached, but the anxiety of the group watching the CD-ROM was significantly lower than the other group. While there was no difference between the two groups in terms of understanding the complications of the surgical procedure, the score that showed the understanding of the subtleties and purpose of the surgical procedure was found to be higher in the group watching the CD-ROM (31). It was reported that the psychological preparation of the patient for the surgery decreased the duration of the hospital stay, the use of analgesics and the complications, and the training videos were effective in increasing the quality of life and the immune response. Also, in various studies, it was reported that preoperative video training would reduce medical costs and be effective in reducing the stress and anxiety associated with surgery $(32,33)$. In our study, the surgical procedures shown in the animations were not performed on live tissue; they were performed on a limb in a virtual environment. Also, these animations did not contain disturbing images such as blood and purulent exudates. This implementation provides that the informed consent process is made more permanent and more satisfactory, by forming an environment in which patient-physician communication increases. Even though the patients were only informed with animations about the disease findings and the stages of the surgery; after the animation, it was seen that patients understood the other treatment options other than the scheduled surgery and the complications related to the operation better and there was a significant increase in their knowledge levels. We think that increasing the visual information about the disease and operation stages of the patients makes the previous information, which was given verbally and in written form, easier to understand and remember. There are some limitations to our study. As a result of our research, we could not find any visual animation applications explaining other treatment options of gonarthrosis and the complications that are specific to total knee arthroplasty. For this reason, we could not provide visual animation to our patients in this respect. We believe that this limitation of our study is also the limitation of visual animation designers. Another limitation of our study is that written/verbal and visual animation applications were carried out on the same patients. Although there was nearly one month's time interval, we still believe this might cause recall bias. The effect of age and gender could not be investigated in the study because the ages of our cases were close to each other, and most of them were female. Also, we did not consider providing information with visual animation proper in terms of the medicolegal approach, which is outside the standard application. For this reason, the control group could not be formed.

\section{Conclusion}

The thought of surgery creates anxiety in the person. This makes understanding of the written consent forms, which are already difficult to understand, more difficult. For this reason, the ways to obtain the informed consent form, which is clear, objective, engaging, and easier to understand for patients at all levels, are needed. The use of visual animations is a simple, easy, and effective method independent of the patient's level of education in informing patients. It also increases patient satisfaction and provides that the patient more easily understands postoperative care and complications.

Ethics Committee Approval: Necessary permissions [istanbul Training and Research Hospital, Clinical Research Ethics Committee; with (decision no: 757, date: 15.01.2016)] were obtained for the implementation of the research.

Informed Consent: It was obtained.

Peer-review: Externally peer-reviewed.

Author Contributions: Surgical and Medical Practices - A.B., Y.Ö.; Concept - Y.Ö.; Design - A.B.; C.G.; Data Collection and/or Processing A.B.; Analysis and/or Interpretation - A.B.; Literature Search - A.B., Y.Ö.; Writing Manuscript - Y.Ö. 
Conflict of Interest: No conflict of interest was declared by the authors.

Financial Disclosure: The authors declared that this study received no financial support.

\section{References}

1. Zachwieja E, Perez J, Hardaker WM, Levine B, Sheth N. Manipulation under anesthesia and stiffness after total knee arthroplasty. JBJS Rev 2018; 6: e2.

2. Kurtz S, Ong K, Lau E, Mowat F, Halpern M. Projections of primary and revision hip and knee arthroplasty in the United States from 2005 to 2030. J Bone Joint Surg Am 2007; 89: 780-5.

3. Ploeger MM, Müller NH, Wirtz DC, Kohlhof H. Obesity in revision total knee arthroplasty-a systematic review and legal assessment. Z Orthop Unfall 2018; 156: 436-42.

4. Nogueira JBS, de Souza Carvalho ACG, de Barros Filho EM, do Carmo Araújo LH, Bezerra MJC, Leite JAD. Planning a total knee arthroplasty through an application for mobile devices: case report. Rev Bras Ortop 2018; 53: 792-6.

5. Ekmekci PE, Ekmekci AB, Karakaș Ö, Kulduk A, Arda B. Evaluation of the informed consent procedure for total knee arthroplasty patients in Turkey. Acta Orthop Traumatol Turc 2016; 50: 400-4.

6. Kheir MM, Rondon AJ, Woolsey A, Hansen H, Tan TL, Parvizi J. Infection following total joint arthroplasty is the main cause of litigation: Data from one metropolitan area. J Arthroplasty 2018; 33: 1520-3.

7. Mussa MA, Sweed TA, Khan A. Informed consent documentation for total hip and knee replacement using generic forms with blank spaces. J Orthop Surg (Hong Kong) 2014; 22: 214-7.

8. Cocanour CS. Informed consent-It's more than a signature on a piece of paper. Am J Surg 2017; 214: 993-7.

9. Dhar H, Dhar D. Informed consent in clinical practice and literature overview. Arch Gynecol Obstet 2012; 286: 649-51.

10. Blake K, Holbrook JT, Antal H, Shade D, Bunnell HT, McCahan SM, et al. Use of mobile devices and the internet for multimedia informed consent delivery and data entry in a pediatric asthma trial: Study design and rationale. Contemp Clin Trials 2015; 42: 105-18.

11. Sivanadarajah N, El-Daly I, Mamarelis G, Sohail M, Bates P. Informed consent and the readability of the written consent form. Ann R Coll Surg Engl 2017; 99: 645-9.

12. Tamariz L, Palacio A, Robert M, Marcus EN. Improving the informed consent process for research subjects with low literacy: A systematic review. J Gen Intern Med 2013; 28: 121-6.

13. Tait AR, Voepel-Lewis T, Zikmund-Fisher BJ, Fagerlin A. Presenting research risks and benefits to parents: does format matter? Anesth Analg 2010; 111: 718-23.

14. Sanchini V, Reni M, Calori G, Riva E, Reichlin M. Informed consent as an ethical requirement in clinical trials: an old, but still unresolved issue. An observational study to evaluate patient's informed consent comprehension. J Med Ethics 2014; 40: 269-75.

15. Kripalani S, Bengtzen R, Henderson LE, Jacobson TA. Clinical research in lowliteracy populations: using teach-back to assess comprehension of informed consent and privacy information. IRB 2008; 30: 13-9.

16. Flory J, Emanuel E. Interventions to improve research participants' understanding in informed consent for research: a systematic review. JAMA 2004; 292: 1593-601.
17. Hussain S, Neilly D, Baliga S, Patil S, Meek R. Knee osteoarthritis: a review of management options. Scott Med J 2016; 61: 7-16.

18. Boyd AD, Ewald FC, Thomas WH, Poss R, Sledge CB. Long-term complications after total knee arthroplasty with or without resurfacing of the patella. J Bone Joint Surg Am 1993; 75: 674-81.

19. Gademan MG, Hofstede SN, Vlieland TPV, Nelissen RG, Marang-van de Mheen PJ, Indication criteria for total hip or knee arthroplasty in osteoarthritis: a state-of-the-science overview. BMC Musculoskelet Disord 2016; 17: 463.

20. Lin Y-K, Chen C-W, Lee W-C, Cheng Y-C, Lin T-Y, Lin C-J, et al. Educational video-assisted versus conventional informed consent for trauma-related debridement surgery: a parallel group randomized controlled trial. BMC Med Ethics 2018; 19: 23.

21. Michalski A, Stopa M, Miskowiak B. Use of multimedia technology in the doctor-patient relationship for obtaining patient informed consent. Med Sci Monit 2016; 22: 3994-3999.

22. Egekeze N, Dubin J, Williams K, Bernhardt M. The Age of Ortholnfo: A Randomized Controlled Trial Evaluating Patient Comprehension of Informed Consent. JBJS 2016; 98: e81.

23. Braddock III CH, Edwards KA, Hasenberg NM, Laidley TL, Levinson W. Informed decision making in outpatient practice: time to get back to basics. JAMA 1999; 282: 2313-20.

24. Akue AH-M, Limousin M, Wavreille G, Fontaine C, Laffargue P, Chantelot C. Contentious matters between doctors and patients in the orthopaedic and traumatology surgery activity of a regional university hospital. Eur J Orthop Surg Traumatol 2008; 18: 449-53.

25. Kraft SA, Constantine M, Magnus D, Porter KM, Lee SS-J, Green M, et al. A randomized study of multimedia informational aids for research on medical practices: Implications for informed consent. Clin Trials 2017; 14: 94-102.

26. Gibon E, Farman T, Marmor S. Knee arthroplasty and lawsuits: the experience in France. Knee Surg Sports Traumatol Arthrosc 2015; 23: 3723-8.

27. Kalala TW. Patients' perceptions and understanding of informed consent for surgical procedures. Johannesburg 2011; 1-77.

28. Jukic M, Kozina S, Kardum G, Hogg R, Kvolik S. Physicians overestimate patient's knowledge of the process of informed consent: a cross-sectional study. Med Glas (Zenica) 2011; 8: 39-45.

29. Ruffinengo C, Versino E, Renga G. Effectiveness of an informative video on reducing anxiety levels in patients undergoing elective coronarography: an RCT. Eur J Cardiovasc Nurs 2009; 8: 57-61.

30. Bowers N, Eisenberg E, Montbriand J, Jaskolka J, Roche-Nagle G. Using a multimedia presentation to improve patient understanding and satisfaction with informed consent for minimally invasive vascular procedures. Surgeon 2017; 15: 7-11.

31. Danino AM, Chahraoui K, Frachebois L, Jebrane A, Moutel G, Herve C, et al. Effects of an informational CD-ROM on anxiety and knowledge before aesthetic surgery: a randomised trial. Br J Plast Surg 2005; 58: 379-83.

32. Ihedioha U, Vaughan S, Mastermann J, Singh B, Chaudhri S. Patient education videos for elective colorectal surgery: results of a randomized controlled trial. Colorectal Dis 2013; 15: 1436-41.

33. Bernstein J, Kupperman E, Kandel LA, Ahn J. Shared decision making, fast and slow: Implications for informed consent, resource utilization, and patient satisfaction in orthopaedic surgery. J Am Acad Orthop Surg 2016; 24: 495-502. 